\title{
RS-1748, a Novel CC Chemokine Receptor 4 Antagonist, Inhibits Ovalbumin-Induced Airway Inflammation in Guinea Pigs
}

\author{
Yasuhiro Nakagami, ${ }^{*, a}$ Yumi Kawase, ${ }^{b, \#}$ Kazuki Yonekubo, ${ }^{a}$ Emi Nosaka, ${ }^{a}$ Maki Etori, ${ }^{a}$ \\ Sakiko TAKahashi, ${ }^{a}$ Nana TAKagi, ${ }^{a}$ Takeshi Fukuda,${ }^{c}$ Takeshi KuribaYAshi,${ }^{c}$ Futoshi NARA, ${ }^{b}$ and \\ Makoto YAMASHITA ${ }^{a}$ \\ ${ }^{a}$ Biological Research Laboratories, Daiichi Sankyo Co., Ltd.; ${ }^{b}$ Exploratory Research Laboratories, Daiichi Sankyo Co., \\ Ltd.; and ${ }^{c}$ Medicinal Chemistry Research Laboratories, Daiichi Sankyo Co., Ltd.; 1-16-13 Kitakasai, Edogawa-ku, Tokyo \\ 134-8630, Japan. Received February 18, 2010; accepted March 4, 2010
}

CC chemokine receptor 4 (CCR4) is generally recognized as a preferential marker for $T$ helper 2 cells, and we have previously reported morpholine-derivative CCR4 antagonists, RS-1154 and RS-1269. Here, we investigate the pharmacological profiles of a novel pyrimidine-derivative CCR4 antagonist, 2-\{4-[2-(diethylamino)ethoxy]phenyl\}- $N$-(2,4-difluorobenzyl)-5-fluoropyrimidin-4-amine (RS-1748), which showed potency to inhibit the bindings of $\left[{ }^{125} \mathrm{I}\right] \mathrm{CCL} 17$ and $\left.{ }^{35} \mathrm{~S}\right] \mathrm{GTP} \gamma \mathrm{S}$ to human CCR4-expressing Chinese hamster ovary (CHO) cells with $\mathrm{IC}_{50}$ values of $59.9 \mathrm{~nm}$ and $18.4 \mathrm{~nm}$, respectively. Furthermore, RS-1748 inhibited ovalbumin-induced airway inflammation in guinea pigs at a dose of $10 \mathrm{mg} / \mathrm{kg}$. These results indicate that RS-1748 would be a promising lead compound for developing a therapeutic agent against asthma.

Key words CC chemokine receptor 4; RS-1748; airway inflammation

CC chemokine ligand 17 (CCL17/thymus and activationregulated chemokine: TARC) and CCL22 (macrophage-derived chemokine: $\mathrm{MDC}$ ) are a pair of $\mathrm{CC}$ chemokines known to selectively bind to $\mathrm{CC}$ chemokine receptor 4 (CCR4). ${ }^{1,2)}$ CCR4 is mainly, even not selectively, expressed on T helper 2 (Th2) cells that produce interleukin (IL)-4, IL-5 and IL$10{ }^{3,4)}$ The presence of Th2 cells in inflammatory sites leads to the occurrence and exacerbation of many allergic diseases such as asthma, atopic dermatitis, allergic rhinitis etc. ${ }^{5)}$ Therefore, chemokine antagonists are attractive targets toward developing medicines against the above diseases, and many researches have been performed to develop chemical CCR4 antagonists and anti-CCR4 antibodies, which are expected to inhibit the pathology of allergic diseases by inhibiting CCR4-dependent cellular migration to inflammatory sites. ${ }^{6}$ These new therapeutic approaches might also give optional prescription, especially to corticosteroids-resistant patients.

We have reported previously that two morpholine derivatives, 3-\{2-[(2R)-2-phenyl-4-(4-pyridin-4-ylbenzyl)morpholin-2-yl]ethyl $\}$ quinazoline-2,4(1H,3H)-dione (RS-1154) and 3-(isobutyrylamino)- $N$-\{2-[(2R)-2-phenyl-4-(4-pyridin4-ylbenzyl)morpholin-2-yl]ethyl $\}$ benzamide (RS-1269), have profiles as CCR4 antagonists. ${ }^{7,8)}$ In this study, we also found a pyrimidine compound, 2-\{4-[2-(diethylamino)ethoxy]phenyl\}-N-(2,4-difluorobenzyl)-5-fluoropyrimidin-4amine (RS-1748, Fig. 1), from screening hits and investi-

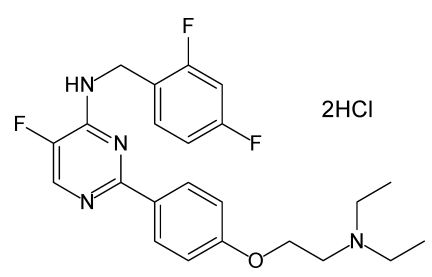

Fig. 1. The Chemical Structure of RS-1748

$\mathrm{C}_{23} \mathrm{H}_{25} \mathrm{~F}_{3} \mathrm{~N}_{4} \mathrm{O} \cdot 2 \mathrm{HCl}$, molecular weight 503.39 . gated its pharmacological profiles using a calcium mobilization assay, $\left[{ }^{125} \mathrm{I}\right] \mathrm{CCL} 17$ binding assay, $\left[{ }^{35} \mathrm{~S}\right]$ guanosine $5^{\prime}-\gamma$ thiotriphosphate (GTP $\gamma \mathrm{S})$ binding assay and an ovalbumininduced airway inflammation assay.

\section{MATERIALS AND METHODS}

Materials Five-weeks old, male Hartley guinea pigs were purchased from Japan SLC, Inc. (Shizuoka), and all experiments were carried out according to the Guidelines for the Care and Use of Laboratory Animals of Daiichi Sankyo Co., Ltd. RS-1748 was synthesized in our laboratory. In the in vitro experiments, RS-1748 was diluted in a solution consisting of $70 \%$ dimethyl sulfoxide and $30 \%$ methanol at a concentration of $5 \mathrm{~mm}$. In the in vivo experiments, RS-1748 was suspended in $0.5 \%$ methyl cellulose $\# 400$ just before use. Human CCR4-expressing Chinese hamster ovary (CHO) cells were generated as previously reported. ${ }^{7,8)}$ Dihydrofolate reductase-deficient $\mathrm{CHO}$ cells were transfected with the plasmid pcDNA3.1(-) carrying guinea pig CCR 4 cDNA, the plasmid carrying chimeric Gqi5 $\alpha$ and the plasmid pSV2dhfr. Stably CCR4-transfected CHO cells were employed for the following experiments.

Calcium Mobilization Assay and Binding Assay For calcium mobilization assay, human CCR4-expressing $\mathrm{CHO}$ cells were plated in Ham's F12 medium containing 10\% fetal bovine serum at a density of $3.5 \times 10^{3} /$ well and guinea pig CCR4-expressing CHO cells were plated in modified Eagle's medium containing $10 \%$ fetal bovine serum at a density of $2.5 \times 10^{3}$ cells/well, and cultured in a humidified atmosphere at $37^{\circ} \mathrm{C}$ for $2 \mathrm{~d}$ in 384 -well plates. Cells were washed with washing buffer ( $25 \mathrm{~mm} N$-(2-hydroxyethyl)piperazine- $N^{\prime}$-2ethanesulfonic acid (HEPES) [pH 7.4$]$ and $2.5 \mathrm{~mm}$ probenecid in HBSS) and loaded with loading buffer $(4 \mu \mathrm{M}$ Fluo3-AM and $0.04 \%$ pluronic acid in washing buffer) for 60 min. After washing, washing buffer with or without RS1748 was added and the cells were cultured for another 
20 min. Without washing, human CCL22 in washing buffer containing $0.1 \%$ albumin was applied. The final concentration of CCL22 was $50 \mathrm{~nm}$ for human CCR4-expressing CHO cells and $100 \mathrm{~nm}$ for guinea pig CCR4-expressing $\mathrm{CHO}$ cells. Changes in the fluorescence were measured by a fluorometric imaging plate reader (FLIPR, Molecular Devices Corp.) at excitation wavelength of $\left.488 \mathrm{~nm} .{ }^{9}\right)$ The binding assay of human CCR4-expressing $\mathrm{CHO}$ cells was performed as described previously. ${ }^{78}$ ) For $\left.{ }^{35} \mathrm{~S}\right] \mathrm{GTP} \gamma \mathrm{S}$ binding assay, the membrane fraction of human CCR4-expressing $\mathrm{CHO}$ cells was prepared. Aliquots of the diluted membranes equivalent to $20 \mu \mathrm{g} / \mathrm{well}$ protein were incubated at room temperature for $60 \mathrm{~min}$ in $100 \mu \mathrm{l}$ of assay buffer (50 mM HEPES [pH 7.5], $100 \mathrm{~mm} \mathrm{NaCl}, 5 \mathrm{~mm} \mathrm{MgCl}_{2}, 5 \mathrm{~nm}$ human CCL22, $5 \mathrm{~nm}$ GDP, $3.5 \mathrm{~nm}\left[{ }^{35} \mathrm{~S}\right] \mathrm{GTP} \gamma \mathrm{S}, 0.1 \%$ albumin, $0.05 \mathrm{mg} / \mathrm{ml}$ saponins and various concentrations of RS-1748) in 96-well plates. The radioactivity was counted by a liquid scintillation analyzer.

Airway Inflammation Assay Ovalbumin-induced airway inflammation was assayed as previously reported ${ }^{10)}$ with some modifications. All guinea pigs were systemically sensitized with immunizing solution on Days 0 and 7 . A challenge procedure consists of reagent oral administration (vehicle or RS- $1748,10 \mathrm{mg} / 2 \mathrm{ml} / \mathrm{kg}, 0 \mathrm{~min}$ ), salbutamol inhalation $(10 \mu \mathrm{g} / \mathrm{ml}, 30-35 \mathrm{~min})$ and ovalbumin inhalation $(10 \mathrm{mg} / \mathrm{ml}$, $35-42 \mathrm{~min}$ ). In some groups, saline inhalation was conducted instead of ovalbumin. This challenge was performed on Days 16, 23 and 30, and bronchoalveolar lavage fluid was collected on Day 31.

Statistical Analysis All data in this study are expressed as means \pm S.E.M. Significant differences of data were calculated by a Tukey's test after an analysis of variance. $\mathrm{The}^{\mathrm{IC}_{50}}$ values were calculated using the program Prism (GraphPad Software, Inc., San Diego, CA, U.S.A.).

\section{RESULTS}

The application of CCL22 induced significant mobilization of intracellular $\mathrm{Ca}^{2+}$ concentration $\left(\left[\mathrm{Ca}^{2+}\right]_{\mathrm{i}}\right)$ (Fig. $\left.2 \mathrm{~A}\right)$. The fluorescence change peaked at $15 \mathrm{~s}$ after the application of CCL22 and the fluorescence gradually decreased. In human CCR4-expressing CHO cells treated with RS-1748 for $20 \mathrm{~min}$ before the application of CCL22, the fluorescence change was smaller than that of non-RS-1748-treated cells. The effects of RS-1748 were investigated in the range of $0.256-20000 \mathrm{~nm}$. RS-1748 dose-dependently inhibited $50 \mathrm{~nm}$ CCL22-induced $\left[\mathrm{Ca}^{2+}\right]_{\mathrm{i}}$ mobilization with an $\mathrm{IC}_{50}$ value of $28.3 \mathrm{~nm}$ (Fig. 2B). Because the loss of species crossreactivity becomes the main problem in developing chemokine antagonists, we also investigated the above effects in guinea pig CCR4-expressing CHO cells. RS-1748 also inhibited $100 \mathrm{~nm}$ CCL22-induced $\left[\mathrm{Ca}^{2+}\right]_{\mathrm{i}}$ mobilization with an $\mathrm{IC}_{50}$ value of $115.8 \mathrm{~nm}$ (Fig. 2C). We next investigated the inhibitory effects of RS-1748 on the binding of $\left[{ }^{125} \mathrm{I}\right] \mathrm{CCL} 17$. RS-1748 showed a competitive displacement activity during the binding of $\left[{ }^{125} \mathrm{I}\right] \mathrm{CCL} 17$ to human CCR4-expressing $\mathrm{CHO}$ cells with an $\mathrm{IC}_{50}$ value of $59.9 \mathrm{~nm}$ (Fig. 3A). The inhibitory effects of the intracellular binding using $\left[{ }^{35} \mathrm{~S}\right] \mathrm{GTP} \gamma \mathrm{S}$ was also checked and RS-1748 inhibited the binding of $\left[{ }^{35} \mathrm{~S}\right] \mathrm{GTP} \gamma \mathrm{S}$ to human CCR4-expressing $\mathrm{CHO}$ cells with an $\mathrm{IC}_{50}$ value of $18.4 \mathrm{~nm}$ (Fig. 3B).

The inhaled challenge of ovalbumin in ovalbumin-sensi-
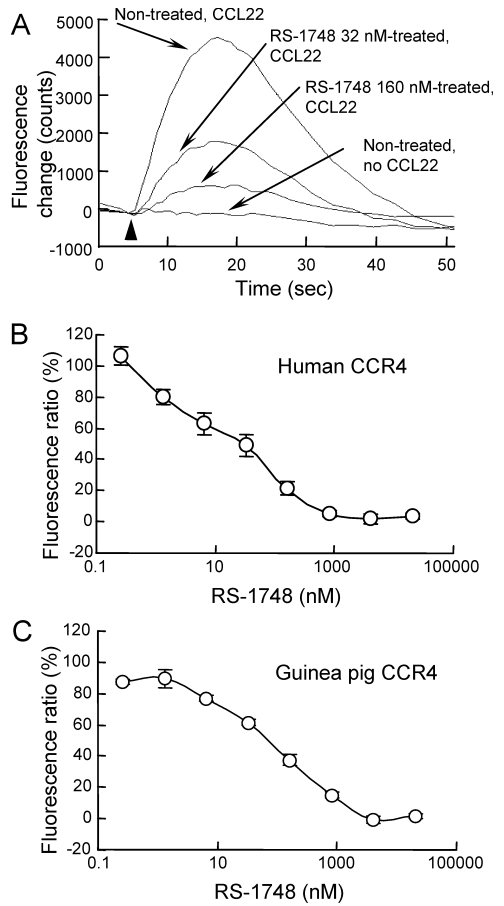

Fig. 2. Inhibitory Effects of RS-1748 on CCL22-Induced $\left[\mathrm{Ca}^{2+}\right]_{\mathrm{i}}$ Mobilization

(A) Fluorescence change of CCL22-induced $\left[\mathrm{Ca}^{2+}\right]_{\text {; }}$ mobilization of human CCR4expressing CHO cells. Cells were treated with RS-1748, $20 \mathrm{~min}$ before the application of CCL22. The arrowhead indicates the timing of application of CCL22. (B) Inhibitory effects of RS-1748 on CCL22-induced $\left[\mathrm{Ca}^{2+}\right]_{i}$ mobilization of human CCR4-expressing $\mathrm{CHO}$ cells. (C) Inhibitory effects of RS-1748 on CCL22-induced $\left[\mathrm{Ca}^{2+}\right]_{\mathrm{i}}$ mobilization of guinea pig CCR4-expressing CHO cells. $n=4$.

tized guinea pigs significantly increased cell numbers in bronchoalveolar lavage fluid (Fig. 3C). Among the cells, the ratio of eosinophils was the largest. We finally investigated the effects of RS-1748 at the dose of $10 \mathrm{mg} / \mathrm{kg}$ and found that the total cell numbers and the eosinophils numbers were significantly lower than those of the vehicle-administered ovalbumin-challenged group.

\section{DISCUSSION}

In this study, we succeeded in obtaining a newly synthesized orally active compound, RS-1748, which has the potential to inhibit $\left[\mathrm{Ca}^{2+}\right]_{\mathrm{i}}$ mobilization of CCR4-expressing $\mathrm{CHO}$ cells, the binding of $\left[{ }^{125} \mathrm{I}\right] \mathrm{CCL} 17$ to CCR4-expressing $\mathrm{CHO}$ cells and the binding of $\left.{ }^{35} \mathrm{~S}\right] \mathrm{GTP} \gamma \mathrm{S}$ to CCR4-expressing $\mathrm{CHO}$ cells in vitro, and to decrease ovalbumin-induced airway inflammation in vivo. The above profile of RS-1748 is similar to that of previously reported morpholine derivatives, RS-1154 and RS-1269, although the chemical structures of the two compounds are quite different from each other. The loss of species cross-reactivity should be overcome in developing chemokine antagonists; however, the antagonism of RS-1748 was confirmed in guinea pig CCR4 as human CCR4. This point would give RS-1748 an advantage to evaluate its efficacy in animals and to be developed in the future. In addition, the chemical structure of RS-1748 is also claimed in the patent published from Mitsubishi Tanabe Pharma Corp. ${ }^{11)}$

The analysis of bronchial biopsies from asthmatics strongly suggests the involvement of the CCR4 system in 

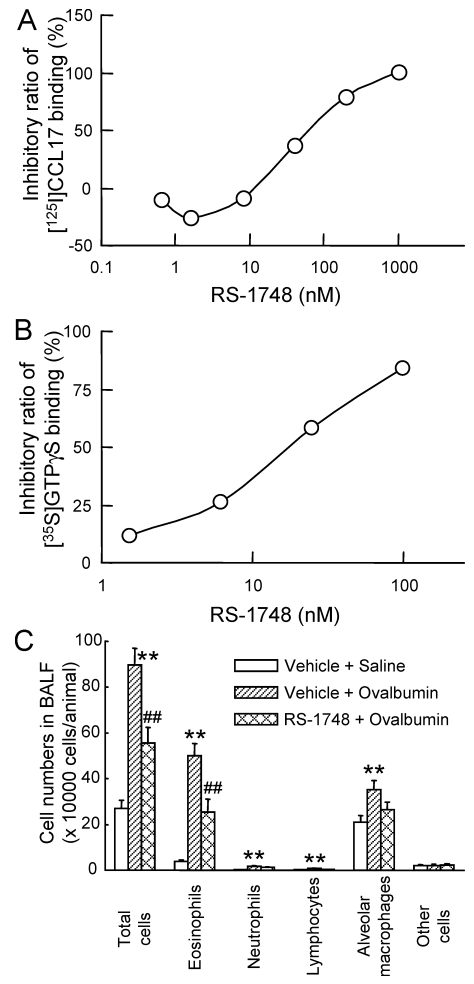

Fig. 3. Inhibitory Effects of RS-1748 in Binding Assays and an in Vivo Assay

(A) Inhibitory effects of RS-1748 on the binding of [ $\left.{ }^{125} \mathrm{I}\right] \mathrm{CCL} 17$. (B) Inhibitory effects of RS-1748 on the binding of $\left.{ }^{35} \mathrm{~S}\right] \mathrm{GTP} \gamma \mathrm{S}$. Human CCR4-expressing cells were used and experiments were performed in duplicate. (C) Inhibitory effects of RS-1748 on ovalbumin-induced airway inflammation. Vehicle + saline: vehicle-administered and saline-challenged group, vehicle+ovalbumin: vehicle-administered and ovalbuminchallenged group, RS-1748+ovalbumin: $10 \mathrm{mg} / \mathrm{kg}$ RS-1748-administered and ovalbumin-challenged group. $* * p<0.01 v s$. vehicle + saline, $\ldots p<0.01 v s$. vehicle + ovalbumin BALF: bronchoalveolar lavage fluid, $n=14-16$ from 3 independent experiments

asthma. ${ }^{12)}$ Many animal studies have also attempted to elucidate the relation between asthma and CCR4; however, the results are not consistent so far. For example, although antiCCL17 and anti-CCL22 antibodies suppressed ovalbumininduced pulmonary inflammation and airway hyperreactivity in mice, CCR4-deficient mice did not show similar phenotypes. ${ }^{13)}$ The same group also found that airway hyperresponsiveness was attenuated when using Aspergillus antigens instead of ovalbumin. ${ }^{14}$ ) To grasp the above results correctly and to validate proof-of-concept of CCR4 antagonists, the expression pattern of CCR4 would be of concern. Indeed, $\mathrm{CD} 4{ }^{+} \mathrm{CD} 25^{+}$regulatory $\mathrm{T}$ cells were demonstrated to strongly express CCR $4,{ }^{15)}$ which might function to attenuate activated $\mathrm{T}$ cells at inflammatory sites. The diversity of chemokines and their receptors, compensation of other chemokine systems during long-term depletion of CCR4 and different roles in different CCR4-expressing cells should be further investigated in detail.

In conclusion, we found a newly-synthesized CCR4 antagonist, RS-1748, which inhibits ovalbumin-induced infiltration of eosinophils into bronchoalveolar lavage fluid. The essential structure of RS-1748 derivatives including its structure-activity relationship still remains to be elucidated; however, this compound would be useful toward evaluating the therapeutic potential of CCR4 antagonists in allergic diseases.

Acknowledgements We are grateful to Dr. Shinichi Kurakata for his critical reading of the manuscript. We would also like to thank Ms. Yuki Sakata and Ms. Kayo Kawashima for their technical assistance in the in vitro experiments, as well as Dr. Shojiro Miyazaki and Dr. Takahide Nishi for their support in the synthesis of CCR4 antagonists.

\section{REFERENCES}

1) Luster A. D., Curr. Opin. Allergy Clin. Immunol., 1, 561-567 (2001).

2) Schwarz M. K, Wells T. N., Nat. Rev. Drug Discov., 1, 347-358 (2002).

3) Bonecchi R., Bianchi G., Bordignon P. P., D'ambrosio D., Land R., Borsatti A., Sozzani S., Allavena P., Gray P. A., Mantovani A., Sinigaglia F., J. Exp. Med., 187, 129-134 (1998).

4) Imai T., Nagira M., Takaga S., Kakizaki M., Nishimura M., Wang J., Gray P. W., Matsushima K., Yoshie O., Int. Immunol., 11, 81-88 (1999).

5) Lloyd C. M., Rankin S. M., Curr. Opin. Pharmacol., 3, 443-448 (2003).

6) Pease J. E., Horuk R., Expert Opin. Ther. Pat., 19, 39-58 (2009)

7) Nakagami Y., Kawashima K., Yonekubo K., Etori M., Jojima T., Miyazaki S., Sawamara R., Hirahara K., Nara F., Yamashita M., Eur. J. Pharmacol., 624, 38-44 (2009).

8) Nakagami Y., Kawashima K., Etori M., Yonekubo K., Suzuki C., Jojima T., Kuribayashi T., Nara F., Yamashita M., Basic Clin. Pharmacol. Toxicol. (in press).

9) Yokoyama T., Kato N., Yamada N., Neurosci. Lett., 344, 45-48 (2003).

10) Mukaiyama O., Morimoto K., Nosaka E., Takahashi S., Yamashita M., Eur. J. Pharmacol., 498, 287-294 (2004).

11) Furukubo S., Miyazaki H., Nakajima T., Ikeda Y., Morokuma K., Nakamaki C., "Heterocyclic Compound," WO2008146914.

12) Panina-Bordignon P., Papi A., Mariani M., Di Lucia P., Casoni G., Bellettato C., Buonsanti C., Miotto D., Mapp C., Villa A., Arrigoni G., Fabbri L. M., Sinigaglia F., J. Clin. Invest., 107, 1357-1364 (2001).

13) Chvatchko Y., Hoogewerf A. J., Meyer A., Alouani S., Juillard P., Buser R., Conquer F., Proudfoot A. E., Wells T. N., Power C. A., J. Exp. Med., 191, 1755-1764 (2000).

14) Schuh J. M., Power C. A., Proudfoot A. E., Kunkel S. L., Lukacs N. W., Hogaboam C. M., FASEB J., 16, 1313-1315 (2002).

15) Iellem A., Mariani M., Lang R., Recalde H., Panina-Bordignon P., Sinigaglia F., D'Ambrosio D., J. Exp. Med., 194, 847-853 (2001). 